\title{
Prioritising employee-organisation relationships in non-profit organisations in Kenya: Antecedents, queries and contradictions
}

Julie Gathoni Gitau, Department of Strategic and Organisational Communication, Daystar University, \& Stella Jerop Chebii, Department of Communication Studies, Moi University< Nairobi, Kenya. Corresponding authoremail: jmuraya@daystar.ac.ke

\begin{abstract}
Although employees are the most critical of organisation publics, it is unclear whether employee-organisation relationships (EORs) in non-profit organisations (NPOs) in Kenya are prioritised. To investigate this question further, the study explored relationship antecedents in two non-profit organisations. The study was informed by relationship management theory and the symmetrical communication framework. Semi-structured, indepth interviews were carried out among 24 purposively sampled management and nonmanagement employees. The data was manually analysed and requisite a priori and in vivo codes and themes identified. The study findings suggest a lack of understanding about the strategic role of public relations in the organisation. Further, technician oriented PR departments mediate the perceptions of and effort expended on internal relationships. Managing employee-organisation relationships was perceived more as a human resource rather than a PR function which precludes more robust forms of PR practice. The researchers recommend a clear demarcation between the public relations and human resource function and to build strategic PR departments that embrace internal relationship management.
\end{abstract}

Key words: Relationship management, employee-organisation relationships, public relations, organisation-public relationships, relationship antecedents

https://doi.org/10.4314/jdcs.v7i1-2.7

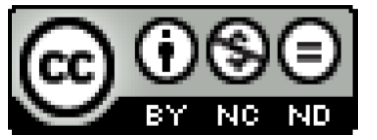

(C) 2020. The authors. This work is licensed under the Creative Commons Attribution 4.0 International License (CC-By-NC-ND). Users may freely share and redistribute this work provided that the author and the Journal of Development and Communication Studies are fully acknowledged. Users may not tweak or remix and offer this work for sale. The full

license may be accessed at https://creativecommons.org/licenses/by-nc-nd/4.0/ 


\section{Introduction}

For over three decades, public relations (PR) scholars have shown a growing interest in the critical role of organisation public relationships (OPRs) and the public relations manager role in managing those relationships that are critical to organisational success. The growth of relationship management studies was largely influenced by the need to demonstrate the value of public relations in the organisation by linking PR activities and strategies to organisational mission.

Despite their proven importance in PR research and practice, organisation public relationships are difficult to measure and relationship management scholars over the years have struggled to measure and theorise this concept. To date there is no single unifying definition or measure of organisation public relationships (Ledingham, 2003). Further, researchers have developed a dizzying lexicon to describe relationship management including: relationship management, organisation-public relationships (OPR), the relational perspective and so on. Public relations scholars credit Ferguson (1984) with bringing relationship management studies to the fore when she suggested that relationships, and not communication, be used as the unit of analysis in PR research. The history of relationship management is somewhat perplexing because after Ferguson's ground breaking study, PR researchers were silent on the subject for nearly ten years until the mid to late 1990s, which witnessed an explosion of interest in OPRs.

In addition to its interesting history, definitions and constructs of relationship management have evolved over time. Huang (1998) was among the pioneer scholars to define relationship management and advance a measurement scale for relationships. She defined organisation public relationships as, "the degree that the organisation and its publics trust one another, agree on who has rightful power to influence, experience satisfaction with each other, and commit oneself to one another" (p.12). Huang's definition captured two of the key concepts in OPR: trust and satisfaction. Trust continues to be a key variable of interest in relationship management studies (Rawlings, 2008; Paine, 2013; Jo \& Shim, 2005; Jiang, 2016) particularly in relation to relationship outcomes.

Contemporaries of Huang (1998), Bruning \& Ledingham (1999), defined OPR as the: "state which exists between an organisation and its key publics in which the actions of either entity impact the economic, social, political, and/or cultural well-being of the other entity" (p. 160). Around the same period, Broom, Casey \& Ritchey (1997; 2000) suggested that, "relationships consist of the transactions that involve the exchange of resources between organisations ... and lead to mutual benefit, as well as mutual achievement" (Broom et al., 2000, p. 91). Suggestions have also been advanced to consider relationship management as a general theory of public relations (Ledingham, 2003).

OPRs are the very core of what makes up the organisation and should not be ignored or trifled with (Phillips, 2006). Organisations are run by people and not systems. It is people who perform the various tasks that help these organisations succeed in fulfilling vision, mission and ultimately, meet the bottom line. It is people who drive sales, present proposals, and team up to carry out tasks and so on. Employees, as key publics in any organisation are impacted by internal communication, organisational decisions and other factors. 


\section{Literature}

The concept, employee-organisation relations (EORs) has become widely accepted in public relations literature although it is a term used in human resource literature as well. Rhee (2004; 2007) was careful to distinguish employee-organisation relationships (EORs) from organisation public relationships (OPRs). OPRs are relationships with external publics while EORs focus on internal relationships. There is a consensus among public relations scholars that employees are the most critical of organisation stakeholders (Grunig, 1992; Grunig et al., 2002; Kim \& Rhee, 2011; Broom \& Sha, 2013).

In defining an EOR, Rhee (2007) emphasised the central role played by communication. An EOR is, "... a connection or association between an organisation and individual employees that necessitates repeated communication" (Rhee, 2007, p. 11). Waters, Bortree \& Tindall (2013) assessed the impact of stewardship on EORs and observed that greater involvement from employees and stewardship from employers had a positive impact on EOR assessment.

The term EOR is shared across disciplines. In human resource literature, the EOR has been described as a psychological contract between employee and employer (Coyle-Shapiro \& Shore, 2007; Tsui and Wang (2002) and involving obligations of reciprocation (Cropanzano \& Mitchell, 2005) between two parties in social exchange studies. EORs are an important factor to organisational success. Internal relationships are linked to job performance, customer service quality and loyalty to the organisation (Kang \& Sung, 2017). In an earlier study, Kim (2007) pointed out that relationship antecedents have been little studied. She explored the possible antecedents for internal relationships in 31 purposively selected Korean organisations by combining constructs from organisational justice, internal communication and organisational communication. Similarly, EOR is a neglected area of study in the whole relationship management milieu (Ni, 2007; 2009; Jo \& Shim, 2005) and several scholars have called for more studies in this area. Further, the role of EORs has also not been adequately studied in non-profit organisations (Williams \& Brunner, 2010). Few studies have been carried out on the subject of employee-organisations relationships in subSaharan Africa

Non-profit organisations (NPOs) in Kenya represent a significant economic factor. By 2000, the sector accounted for over US\$200 million in expenditure, which translated into $2.5 \%$ of the country's gross domestic product (GDP). In addition, the non-profit sector in Kenya employed about $2.1 \%$ of the economically active population and by 2005, NPOs numbered over 300,000 registering a three-fold increase from 1997 when the total number of NPOs in Kenya stood at slightly over 113,000, (Kanyinga \& Mitullah, 2009). Non-profit (or not for profit) is one of three organisational sectors, where the focus is on mission rather than making profits. The other two sectors are public sector and private (for profit) organisations (Meyer \& Leixnering, 2015). Out of the seven categories of NPOs in Kenya, NGOs grew from 5600 in 2008 to over 8000 by 2012. Significantly, by 2012 they had injected over US\$747 million to the Kenyan economy (NGO bureau, 2019).

Often, NPOs compete with profit-making organisations to retain competent staff. Subsequently, cultivating relationships with prospective donors (Waters, 2008, 2009); communities (Penning, 2014) and other specialised publics becomes a core task of public relations managers working in these organisations often because their survival depends on 
initiating and maintaining healthy EORs and OPRs. Hon \& Grunig's (1999) instrument for measuring relationships has been widely validated Kim (2001; 2007). Grunig \& Huang (2000) extended this original framework (Hon \& Grunig, 1999) suggesting that relationships may be studied through three stages: relationship antecedents, relationship cultivation strategies and relationship outcomes. The model, however, does not suggest a linear progression of OPRs from one stage to the next.

Relationship antecedents, the focus of this present study, are factors that cause organisation relationships to develop. The purpose of this study was to explore if an understanding of relationship antecedents could shed light on whether internal publics are a key focus of public relations managers. Relationship antecedents include perceptions, motives, needs and behaviours in addition to other factors (Kim, 2007). In their study on relationship antecedents, Botha \& Waldt (2010) applied Grunig \& Huang's (2000) model to identify emerging relationship antecedents in relation to strategic alliances and relationship outcomes, while Bortree (2011), in a different study, explored the motivation for adolescent volunteers in organisations. Scholarly interest in relationship antecedents has been wanting (Ni, 2007; 2009; Jo \& Shim, 2005), which underscores the importance of this present study. This study was guided by the following research question (RQ):

RQ How do relationship antecedents centralise the importance of internal relationships and the public relations manager's role in managing employee-organisation relationships in non-profit organisations?

\section{Method}

This qualitative case study allowed the researchers to delve into participants' lived in experiences in relation to the central question in this research. Yin, $(2014 ; 2018)$ identifies understanding of lived experiences as core to qualitative case study research. The top management of seven NPOs were approached to participate in this study, however, only two agreed. The criteria for inclusion of organisations in this study were that they be nonprofit organisations and have public relations departments. Participants in both organisations, were also purposively sampled in order to capture variant views from both management and non-management employees. Since both organisations requested anonymity, one organisation is identified as AME and the other, FBU.

AME is a healthcare NGO with over 1000 employees in its regional and local (Kenyan) offices. This organisation has countrywide operations in several preventative and curative health services and health promotion activities. For the purposes of this study, the initials AME identify this organisation. A key informant in this organisation facilitated entry into the organisation.

Out of the initial 20 people contacted, 13 agreed to participate in the research. These participants comprised top and middle level managers, team leaders, administrative personnel, and lower cadre employees. Snowball sampling was used to identify the nonmanagement participants in this organisation since initial contact was with top and middle level managers. FBU is a faith based organisation (FBO); a university with over 300 employees. FBOs represent a distinct category of non-profit organisations that draw their mission and values from their faith (Bielefeld \& Suhs, 2013). Eleven individuals agreed to 
participate in the study comprising top and middle level management, faculty, and administrative staff. His organisation requested anonymity and is identified with the initials FBU.

All participants in the study were informed of their voluntary participation and gave their written consent prior to the study. Due to the sensitive nature of the subject under study, care was taken not to identify participants in any way that would cause them harm. This practice is supported in similar studies Hung (2005) and is recognised in qualitative research Rossman \& Rallis, (2012). Semi-structured in-depth interviews were conducted with the 24 participants from the two organisations. The study combined active interviewing as suggested by Hung (2005) and Rubin \& Rubin's (2012) responsive interviewing, which allows the researcher to build a relationship with interviewees in the course of data gathering.

All interviews were recorded and varied in length from 45 minutes to over an hour. Interview data were gathered until saturation (Glaser and Strauss, 1967) was reached. There is a general consensus among researchers that data saturation varies from one study to another and is reached when there is no new data, themes or codes as was the case in this present study. Further, data saturation is more about the depth (richness) of data than numbers (Fusch and Ness, 2015).

The interviews were transcribed verbatim by a research assistant (RA) and care was taken to capture important nuances such as silence, hesitation, non-verbal behaviour to add to the richness and thickness of data (Ponterreto, 2006). The data were manually analysed as recommended by Bazeley (2013), who suggested that manual analysis puts the researcher more in touch with the data. The researchers identified in vivo and priori codes from which themes were drawn (Saldana, 2013). A priori codes are derived from the theory used in a study, while in vivo coding allows the researcher to use the exact words of participants (Saldana, 2013; Bazeley, 2013). Care was to taken to maintain the trustworthiness of this research by guarding against researcher bias. The following results section includes major themes that emerged from the study. After multiple in-depth analysis of the interviews, the researchers identified the following themes.

\section{Results}

\section{Employees do not come readily to mind in relation to other stakeholders}

One of the initial questions participants were asked was: "Who are the key stakeholders in this organisation?" None of the participants in the two organisations mentioned employees. Rather, donors, the community (the organisation serves), government, students and other (mostly external) publics came more readily to mind than did employees. Only when prompted did participants extol the importance of employees. AME 1 described employees as, "organisation heroes," and "the most important assets in the organisation." Further, employees were described as those who serve and own the organisation, because they deliver on the organisation's vision, mission and strategy meaning. In short, employees were valued in relation to their input to the organisation.

Most participants (80\%) in FBU, across the management and non-management divide tended to rank organisation stakeholders in order of importance with employees coming third after students and parents (sponsors). FBU 1 described employees as critical 
to upholding organisational reputation and thus "...should be taken care of better..." A related response described employees as organisation ambassadors who deliver on the organisation's mandate (FBU 2).

\section{Employees are valued in relation to their contribution towards organisation objectives}

The concept of "cogs in the wheel" came up with AME 2 who expressed concern that the EORs often do not to go beyond work. Further, EORs were viewed as interdependent and valuable for fostering "co-existence" in the organisation. A different participant in management, AME 3, made the important observation that in comparison to profit making organisations, NPOs do not invest as much in EORs. In her opinion, top management and donors would be hard pressed to support line budgets for building EORs in addition to core functions. AME 3 also mentioned a culture of laxity in NPOs with a perceived minimal effort to build internal relationships.

...From the commercial, private sector where there was a lot of focus on employee relationships, employee empowerment. At the end of the day, they are looking at income for the oganisation and even their deliverables are very specific. They are smart. So to get this employee to do their best, then they also invest a lot on them. In NGO I would say you mainly just do your job... (AME 3)

One long serving participant in FBU, (FBU 3), described the importance of EORs in relation to the role of an employee as "one who gives service to the organisation." FBU 3 emphasised the Christian values of the organisation that clearly had a bearing on this response. In contrast, one middle level manager in the same organisation said that the organisation's relationship with employees did not go beyond the bottom line.

“... I think they will have a relationship with you as far as it relates to your work and maybe they will support you so that you can be more efficient in your work. So, I think for them it is to maximize your efficiency at work. It is about the bottom line...I think it is the tragedy of all organisations. They have to think about the bottom line. They have to think about how efficient you can be and so in a sense you are, most of the times, reduced to working robots. (FBU 4)

\section{Perceptions about having a relationship with the organisation}

Participants were asked whether they believed that they had a relationship with their respective organisations. Drawn from Grunig's qualitative tool (IPR, 2002) for investigating OPRs this closed ended question was difficult for most participants to answer judging from the prolonged silence it elicited. There were variable responses to this question. About $80 \%$ of the participants in AME and FBU believed that they have a relationship with their respective organisations. These were mostly long-serving employees who had worked for more than ten years. Only $20 \%$ of the participants in the two organisations said that they did not have a relationship with their organisations. The perspectives of the latter were 
tempered by crises that the two organisations were undergoing at the time of the study. AME had a retrenchment exercise and FBU a students' strike. These events somewhat dampened their affinity to their respective organisations and had a bearing on their relationship with the organisation at the time.

\section{Relationship Antecedents}

\section{Organisation orientation activities as antecedent}

Participants in both organisations were asked to identify the relationship antecedents. The term antecedent was operationalised by asking the question: "In your opinion, what are some of the reasons that this organisation develops a relationship with its employees? About $70 \%$ of the participants in both organisations identified organisation orientation activities for new employees as an important antecedent as one AME participant demonstrates:

I think the measures and even how staff is inducted into the organisation ...it's how you're introduced to different parts of the organisation and the team that you'll be working with and getting to understand what these people are doing and this is how my role might relate to this other unit. So, I think that's one way that the organisation has to create some relationships (AME 2)

\section{Organisation mission and core values as antecedent}

Organisation mission was an important theme for all participants in the two organisations although they approached it differently. AME participants emphasised the importance of the community as part of the overall mission of the organisation. This excerpt from AME 1 demonstrates this.

We put the communities (we serve) at the centre of what we do as an organisation. We work a lot with disadvantaged and marginalized communities so it is a big thing that we are able to make a difference (AME 1)

The consistent mention of moving towards fulfilling organizational mission was mentioned quite frequently by participants in AME. In an apparent contradiction, a different participant, AME 4 pointed out that the organisation only initiated EORs when there was a crisis."...I would say that there is a reactionary type of response to building relationships [and this is] usually when something is going wrong ..."

FBU participants focused more on the core values that emanate from the organisation's mission as an important factor around which employee-organisation relationships are built. FBU 5 said the EORs should be built around the organisation, while a different participant in middle level management (FBU 6) pointed out that structures were only as good as if they allowed for two-way communication between employees and top management:

\section{Organisation structure as antecedent}

About $50 \%$ of the participants agreed that EORs are initiated at the organisation structure level where the clear reporting lines, vertically and horizontally, provide the basis for a work 
relationship to begin and continue. In addition, organisation structures and policies on interaction guide reporting relationships and employee behaviour. About 15\% of the participants in AME said EORs begin at the department or project level, which has important implications for the team leader, project managers of different projects and their role in initiating and maintaining EORs.

...the vastness of the organisation means it can take a long time for the organisation to come down and listen to what I have to say because of the diversity and the priorities in place...it takes time for the organisation to feel each and every person (AME 2)

An FBU participant offered a related perspective and perceived organisation structure as a way to ensure that people are heard:

"...there is still the element of structures in place where voices can be heard whether you are looking at the bodies that are there for general staff or for management...I am looking at structures that enhance communication, structures that allow for ideas to be discussed or voices to be heard..." (FBU 1)

\section{Organisational leadership culture as relationship antecedent}

One overriding theme that emerged from the two organisations was the critical role of organisational leadership as a precursor to organisational relationships. Nearly $50 \%$ of the participants in the two organisations highlighted organisational leadership. The following excerpt from FBU 7 best illustrates this theme:

...The reason as to why the CEO (Chief Executive Officer) comes in uniquely is because he is the vision bearer... So he is supposed to structure it in a way that it is going to tilt all the relationships under him to function or work towards the vision that he has for the university... (FBU 7)

\section{Who is tasked with managing EORs?}

\section{Perception that managing EORs is a function of human resource and not public relations}

One of the prevailing themes in both organisations was the belief that the role of building and nurturing EORs lies with the human resource department and not public relations. When asked whose role it was to manage EORs, none of the respondents in AME mentioned the public relations manager. The majority $(90 \%)$ of the declared that the custodian of EORs was the human resource (HR) manager. These participants saw the HR role extending beyond hiring, firing, "onboarding" (orientation) activities, and capacity development to that of building EORs.

...I think for me the biggest stakeholder that I feel needs to be in charge (of EORs) is the human resource department because there will always be suspicion between management and general staff. Management focus will be 
on leadership. They may not really focus on people. And people ideally may fear whatever comes down from management. But I would put the biggest burden on the HR department because HR ideally deals with the human aspect of the workplace... (FBU 1)

\section{Perception that managing EORs lies with top management}

Other participants said the role of managing EORs lay with management including middle level (heads of departments, deans and other team leaders).

... it all begins at the top leadership because organisations thrive and fall on leadership. So what the top leadership demonstrates is what will be cascaded to the operational levels of management, the supervisors and the way down to the shop floor. So, if that is not demonstrated at the top, it will play in the middle, all the way to the bottom. And, therefore, I would say the responsibility lies with the top leadership, starting with the CEO... (FBU 7)

Only two participants in both organisations said that the role of building and nurturing EORs falls with the public relations department. Both had studied public relations. One participant in FBU, pointed out the tension between HR and PR roles:

... public relations (here) deals more with external publics or the people that relate to students, [and] sponsors. They tend to focus more on that. But I guess ... there also needs to be a kind of agreement that we know where does HR stops and where does public relations department pick up?...(FBU 8)

\section{Discussion}

The majority of the participants from the two organisations in this study made references to communication while describing employee organisation relationships. Communication terms such as vertical, upward communication, interaction brings to the fore, Yang \& Taylor's (2014) research which suggests EORs may be studied using a network ecology. Beyond this, the reference to internal communication underscores Rhee's (2004; 2007) research that highlighted its inextricable link with employee-organisation relationships. Reporting lines as mentioned by participants denote organisational structure, which guides reporting relationships and communicative behaviour. Besides internal communication, organisation mission and organisational structure were also identified as important relationship antecedents. In this regard, the findings for this study corroborate Kim's (2007), who identified internal communication and organisations structure as relationship antecedents.

In both organisations, participants were uncomfortable with the question that explored whether or not they had a relationship with their respective organisation; a finding that confirms what similar studies found (Botha \& Waldt, 2010). Scott (in Botha \& Waldt, 2010) identified the problematic wording of the question, which brings into focus the versatility of Grunig's (IPR, 2002) qualitative instrument for exploring employeeorganisation relationships. 
Managers and non-management staff in both organisations agreed that employees are critical stakeholders, but only after they were prompted, which was contradictory. For most participants, other publics including community, media, government and clients came more readily to mind than did internal publics. Participants in both study sites also agreed that employees' perceptions may affect the reputation of the organisation underscoring what other studies have found.

Based on their observation of public relations manager roles in their respective organisations, participants reported that this role focused more on external rather than internal publics. Image building, publicity and marketing activities were identified as the main role of public relations in the organisation. Importantly, participants understood this role to fall under the human resource manager, yet they were unable to articulate how the HR manager would actually manage internal relationships.

Significantly, this finding raises a concern among PR professionals about the intrusion of other fields, particularly human resources management and marketing, into their territory. Literature on this subject is scant although Lauzen's $(1991,1992)$ research explored the phenomenon, where marketers and human resource personnel were more likely than others to invade PR territory. She lays the blame for this on PR practitioners who often, in her view, cede ground to these other professions in the organisation.

Encroachment of other disciplines into PR space is part of a wider conversation beyond this study and is one of the key factors driving the Institute of Public Relations and Communication (IPRC) bill proposed by the Public Relations Society of Kenya (PRSK). The Bill, among other things, seeks to professionalise PR practice in Kenya through legislature and proposes, among other things, to lock out those who have no formal training in PR from practicing in the field (PRSK, 2018). On the contrary, public relations research has also been criticized for extending itself into other fields without firming up its own theoretical grounding (Duhring, 2015); (L'Etang, 2012).

\section{Conclusion}

The findings of this research underscores the perennial call for strategic public relations management of which relationship management is core, (Center and Jackson, 1995; 2014; McNamara, 2014). Importantly, this study points towards the need to build the capacity of public relations managers in NPOs beyond the publicity and marketing communication function, to a more strategic one which embraces internal relationships. The relationship antecedents identified in this study become an important focal point for enhancing and strengthening the organisation's internal structures, reputation and building loyalty amongst employees.

\section{Recommendations}

This study also points towards the importance of training in public relations. Lack of training could possibly explain why PR managers often fail to have an impact in the organisation and may explain why the role is often misunderstood. Proper training of PR professionals also has implications on who is hired to carry out public relations work meaning that organisations need to pay more attention to hiring trained PR personnel. A more strategic approach to PR in organisations would also clearly delineate and distinguish 
it from the human resource function. The researchers also suggest that studies on employeeorganisation relationships would benefit from mixed research for richer findings. In addition, EORs can be studied longitudinally and during periods of organisation change when it is important to understand the impact of that change on employees. This study explored EORs in the non-profit sector. Further research may explore EORs in the public and private sectors in addition to NPOs offering a comparative analysis of the three sectors.

\section{References}

Bazeley, P. (2013). Qualitative data analysis: Practical strategies. Sage: London.

Berger, B. (2008). Employee/Organisational Communications.

https://instituteforpr.org/employee-organisational-communications/. Retrieved on February 1, 2018,

Bielefeld, W. \& Subs, W. (2013). Defining faith-based organisations and understanding them through research. Non-profit and Voluntary Sector Quarterly, 42(3), 442-467. https://doi.org/10.1177/0899764013484090. Retrieved on March 4, 2020.

Bortree, D.S. (2011). Mediating the power of antecedents in public relationships: A pilot study. Public Relations Review, 37 (1) 44-49.

https://doi.org/10.1016/j.pubrev.2010.11.002. Retrieved on February 1, 2018.

Botha, E., \& Waldt, D. (2010). Relationship antecedents that impact on outcomes of strategic stakeholder alliances. African Journal of Business Management, 4 (8) 1629-1638. Retrieved on October 10, 2015.

Broom, G.M., Casey, S., and Ritchey, J. (1997). Toward a concept and theory of organisation-public relationships. Public Relations Review, 9 (2) 83-98. Retrieved d on January, 28, 2016.

Broom, G., Casey, S., \& Ritchey, J. (2000). Toward a concept and theory of organisationpublic relationships: An update. In J. A. Ledingham \& S. D. Bruning (Eds.), Public relations as relationship management: A relational approach to public relations (pp.322). Mahwah, NJ: Lawrence Erlbaum Associates, Inc.

Broom, G. M., \& Sha, B.L. (2013). Cutlip E Center's effective public relations (11 $\left.{ }^{\text {th }} \mathrm{ed}\right)$. Upper Saddle River, NJ: Pearson.

Bruning, Stephen D., and John A. Ledingham. (1999).Relationships between organizations and publics: development of a multi-dimensional organization-public relationship scale. Public Relations Review, 25 (2) 157. Retrieved on 25 May 2020.

Cropanzano, R \& Mitchell, M.S. (2005), “Social exchange theory: an interdisciplinary review", Journal of Management, 31 (6) 874-900. Retrieved on January, 28, 2016.

Ferguson, M. A. (1984, August). Building theory in public relations: Interorganisational relationships. Paper presented at the annual convention of the Association for Education in Journalism and Mass Communication, Gainesville, FL. Retrieved on February 13, 2016.

Fusch, P.I. \& and Ness, L.R. (2015) Are We There Yet? Data Saturation in Qualitative Research. The Qualitative Report, 20, 9, pp. 1408-1416. Retrieved on May 24, 2020.

Glaser, B, \& Strauss, A.L. (1967). The Discovery of Grounded Theory Strategies for Aldine Transaction. A Division of Transaction Publishers. New Brunswick, USA. 
Grunig, J.E. (1992), "Symmetrical systems of internal communication”, in Grunig, J.E., Dozier, D.M., Ehling, W.P., Grunig, L.A., Repper, F.C. and White, J. (Eds), Excellence in Public Relations and Communication Mangement, Lawrence Erlbaum Associates, Hillsdale, NJ, pp. 531-575.

Grunig, J.E. \& Huang, Y.H. (2000). “From organisation effectiveness to relationship indicators: antecedents of relationships, public relations strategies and relationship outcomes" in Ledingham, J.A. \& Bruning, S.D. (Eds). Public relations as relationship managemnt: A relational approach to the study and practiceof public relations. Mahweh, NJ: LEA.

Grunig, L.A., Grunig, J.E. and Dozier, D.M. (2002), Excellent Public Relations and Effective Organisations: A Study of Communication Management in Three Countries. Lawrence Erlbaum Associates: Mahwah, NJ.

Grunig, J.E. (2002). Qualitative Methods for Assessing Relationships between Organisations and Publics. IPR. Retrieved on 25 August 2017.

Hon, L.C., \& Grunig, J.E. (1999). Measuring relationships in public relations. Gainesville, FL: Institute for Public Relations.

Huang, Y. (1998, August). Public relations strategies and organisation-public relationships. Paper presented at the annual conference of the Association for Education in Journalism and Mass Communication, Baltimore. Retrieved on February 13, 2016.

Huang, Y. (2001). OPRA: A Cross-Cultural, Multiple-Item Scale for Measuring Organisation-Public Relationships. Journal of Public Relations Research, 13(1) 61-90. DOI: 10.1207/S1532754XJPRR1301_4. Retrieved on February 13, 2016.

Hung, C. F. (2005). Exploring types of organisation-public relationships and their implications for relationship management in public relations. Public Relations Review, 17(4), 393-426. Retrieved on February 13, 2016.

Jiang, H. (2016). Cultivating Employee Trust: From Authenticity, Transparency to Engagement. IPR. Retrieved on 25 August 2017.

Jo, S. \& Shim, S.W. (2005). Paradigm shift of employee communication: The effect of management communication on trusting relationships. Public Relations Review. 31(2) 277-280. DOI: 10.1016/j.pubrev.2005.02.012

Kang, M. \& Sung, M. (2017) "How symmetrical employee communication leads to employee engagement and positive employee communication behaviours: The mediation of employee organisation relationships", Journal of Communication Management. 21 (1) 82-102, https://doi.org/10.1108/JCOM-04-2016-0026. Retrieved on 25 August 2017.

Kanyinga, K. \& Mitullah, W. (2009). The non-profit sector in Kenya: What we know and what we don't know. Nairobi: Institute for development studies. University of Nairobi. Retrieved on 25 August 2017.

Kim, Y. (2001). Searching for the organisation- public relationship: a valid and reliable instrument. J EMC Quarterly, 78 (4) 799-815. Retrieved from AEJMC 799. Retrieved on October 10, 2015. 
Kim, H.S. (2007) A Multilevel Study of Antecedents and a Mediator of EmployeeOrganisation Relationships, Journal of Public Relations Research, 19 (2) 167-197, DOI: 10.1080/10627260701290695. Retrieved on 25 August 2017.

Kim, J.N. \& Rhee, Y. (2011), "Strategic thinking about employee communication behaviour (ECB) in public relations: testing the models of megaphoning and scouting effects in Korea", Journal of Public Relations Research, 23 (3) 243-268, doi: 10.1080/1062726x.2011.582204. Retrieved on 25 August 2017.

Lauzen, M.M. (1991). Imperialism and encroachment in public relations. Public Relations Review 17 (3) 245-255. https://doi.org/10.1016/0363-8111(91)90021-C. Retrieved December 11, 2019.

Lauzen, M.M. (1992). Public relations roles, intraorganisational power, and encroachment. Public Relations Review. 4 (2) 61-80. https://doi.org/10.1207/s1532754xjprr0402 01. Retrieved December 11, 2019.

L'Etang, J. (2008). Public relations, practice and critique. London: Sage.

L'Etang, J. (2012). Public relations concepts, practice and critique. London: Sage.

Macnamara, J. (2005). The New Australian and New Zealand public relations manual. Research and Evaluation. pp. 100-134. Retrieved on December 11, 2019.

Macnamara, J. (2014). Emerging international standards for measurement and evaluation of public relations: A critical analysis. Public Relations Inquiry. 3 (1) 7-29. doi:10.1177/2046147X14521199. Retrieved on September 9, 2015.

Meyer, R., E Leixnering, S. (2015). Public Sector Organizations. In J. D. Wright (Ed.). International Encyclopaedia of the Social and Behavioural Sciences ( $\left.2^{\text {nd }} \mathrm{ed}\right)$. Orlando, FL: Elsevier.

Ni, L. (2007), “Redefined understanding of perspectives on employee-organisation relationships", Journal of Communication Management. 11(1) 53-70. http: //dx.doi.org/10.1108/13632540710725987. Retrieved on September 9, 2015.

Ni, L. (2009), "Strategic role of relationship building: perceived links between employeeorganisation relationships and globalization strategies", Journal of Public Relations Research. 21 (1) 100-120. Retrieved on September 9, 2015.

Paine, K.D. (2013). Guidelines for Measuring Trust in Organisations. Gainesville, FL: IPR. Retrieved on December 11, 2019.

Penning, T. (2014). The influence of public relations on relationship content: A content analysis of community foundation annual reports. PRism 11(2): http://www.prismjournal.org/homepage.html. Retrieved on June 24, 2016.

Phillips, D. (2006). Towards relationship management. Journal of Communication Management, 10 (2) 21-226. http://dx.doi.org/10.1108/13632540610664751. Retrieved on March, 42016.

Ponterreto, J.G. (2006). Brief Note on the Origins, Evolution, and Meaning of the Qualitative Research Concept “Thick Description”. The Qualitative Report, 11 (3) 538549. Retrieved on September 30, 2015.

Rhee, Y. (2004). The Employee-Public-Organisation Chain in Relationship Management: A Case Study of a Government Organisation. Institute for Public Relations, Gainesville, FL: Institute for Public Relations. 
Rhee, Y. (2007), "Interpersonal communication as an element of symmetrical public relations: a case study", in Toth, E.L. (Ed.). The Future of Excellence in Public Relations and Communication Management, Lawrence Erlbaum, Mahwah, NJ, pp. 103-117. Retrieved on June 24, 2016.

Rossman, G.B. \& Rallis, S.F. (2012). Learning in the field: An introduction to qualitative research. LA: Sage.

Rubin, H.J. \& Rubin, I.S. (2012). Qualitative interviewing: The art of hearing data ( $\left.3^{\text {rd }} e d\right)$. Thousand Oaks, California: Sage.

Saldana, J. (2013). The coding manual for qualitative researchers ( $2^{\text {nd }}$ ed). LA: Sage.

Tsui, A. and Wang, D. (2002), “Employment relationships from the employer's perspective: current research and future directions", International Review of Industrial and Organisational Psychology, Vol. 17, 77-114. Retrieved on June 24, 2016.

Waters, R. D. (2008). Applying relationship management theory to the fundraising process for individual donors. Journal of Communication Management, 12(1) 73-87. Retrieved on December 12, 2018.

Waters, R. D. (2009). Measuring stewardship in public relations: A test exploring impact on the fundraising relationship. Public Relations Review, 35, 113-119. Retrieved on December 12, 2018.

Waters, R.D., Bortree, D.S. \& Tindall, N.T. (2013). Can public relations improve the workplace? Measuring the impact of stewardship on employer-employee relationships. Employee Relations, 35 (6) 613-629. DOI: 10/1108/ER-12-2012-0095. Retrieved on December 12, 2018

Yang, A. Taylor, M. (2014). Looking over, Looking out, and Moving Forward: Positioning public relations in Theorising Organisational Network Ecologies. Communication Theory, doi.10.111/comt.12049. Retrieved on December 11, 2019.

Yin, R.K. (2014). Case study research: Design and methods (5 $\left.5^{\text {th }} \mathrm{ed}\right)$. LA: Sage.

Yin, R.K. (2018). Case study research and applications: Design and methods. LA: Sage. 